\title{
Effects of Religiosity on Apparel Shopping Orientation: An Exploratory Study
}

\author{
Lizhu Davis \\ California State University, Fresno \\ Tun-Min (Catherine) Jai \\ Texas Tech University
}

\begin{abstract}
Although religion is an important cultural element that affects a society's value system and its people's behavior, limited research has studied effects of religion on consumers' patronage behavior, especially when it comes to apparel. This study, therefore, explored religiosity and consumers' apparel shopping orientation. The findings reveal that religiosity significantly affect Christian consumers' apparel shopping orientation. Specifically, religiosity has a significant positive direct effect on quality consciousness, fashion consciousness, and price consciousness. The study indicates fashion retailers should understand the role of religiosity on consumers' patronage behavior, thus delivering better value to their customers.
\end{abstract}

\section{INTRODUCTION}

Although sociologists have been studying the relationship between religion and human behavior since the early $20^{\text {th }}$ century (e.g. Durkheim, 1912), marketers and consumer behavior researchers only started to pay attention to the effects of religion in the consumer market since the 1980s. Some scholars pointed out that as a key element of culture, religion not only provides conduct code that modifies its believers' behavior and affects society's value system, but also affects consumers' consumption and shopping behavior (e.g. Bailey \&Sood, 1993; Hirschman, 1981; Sheth, 1983). For example, Sheth's (1983) integrative theory of retail store patronage preference and behavior suggests that religion is a consumer value and it may affect the consumer's shopping motivation. Until recently, limited studies investigating the effect of religion on consumer behavior have been published in the marketing and consumer behavior research journals for a number of reasons, includingthe sensitive of its topic, validity of measurement scales, methodology issues, and lack of theory (Swimberghe, Flurry, \& Parker, 2011). Therefore, little is known on how religion affects consumers' decision making process and other behaviors in the marketplace (Muhamad\&Mizerski, 2010).

Consumer behavior research on religion has two major focuses: religious affiliation and religious commitment. Earlier research focuses more on the relationship between religious affiliation and consumer behavior variables. However, while some studies found religious affiliation a significant factor affecting such variables as purchase decisions (Hirschman, 1982), others fail to provide evidence in other areas of consumer behavior such as retail store evaluation criteria (McDaniel \& Burnett, 1990). Religious 
commitment is also commonly termed as religiosity in marketing literature. Religiosity affects consumers' consumption and shopping behavior such as shopping orientation (e.g. Hirschman 1981;Mokhils 2009) and store choice criteria (e.g. McDaniel \& Burnett, 1990). Some researchers (e.g. Essoo\&Dibb, 2004) argue that religiosity is a stronger affecting factor than religious affiliation. Therefore, understanding the effects of religiosity on consumer behavior such as consumption decision processes may significantly address the effectiveness of global marketing strategies (Delener, 1994). However, little empirical evidence exists that verify how religion influences the way people shop (Essoo\&Dibb, 2004). More research is needed to investigate the effect of religiosity on retail patronage behavior (Moschis\& Ong, 2011; Swimberghe, Sharma \&Flurry, 2009).

Religion in the United States has been under-researched (Cleveland \&Chang, 2009). Inthe past two recent decades, the majority of consumer behavior research on religion was conducted in countries such as Thailand and Malaysia, and only few were done in theUnited States. However, the United States is a highly religious country. Based on US religious landscape survey (Pew Forum on Religion and Public Life, 2008), 78.4\% of US adults describe themselves as Christians. Within the broader Christian market, there is a rapid growing segment: faith driven consumers (Christian consumer segment ready to switch to compatible brands, 2012). This segment includes more than 46 million Americans with $\$ 1.75$ trillion in annual spending power. Based on annual spending power, this market is nearly twice the size of the African American market and three times the size of the Asian American market (Targeting the $\$ 1.75$ trillion faith driven consumer market, 2012). It becomes critical to study how religion and faith affect consumers' shopping and consumption behavior in today's marketplace in the United States. Companies that ignore the role of religion on consumer behavior may find themselves suffering in the marketplace. For example, one study shows (Swimberghe, et.al, 2011) that highly religious consumers not only morally judge companies that support controversial causes that are contrary to their religious values, but also express their dissatisfaction through protest and boycott.On the other hand,among marketing and consumer behavior researches on religion, no researchesthat we are aware of have studied the relationship between religion and consumer apparel shopping and consumption behavior. Therefore, the purpose of this study was to explore the effect of religiosity on Christian consumers'apparel shopping orientation. The findings of the study will provide valuable information to fashion retailers in order to better serve their customers, especially those living in regions and cities where religion is an important part of their life.

\section{LITERATURE REVIEW}

\section{Religiosity and Consumer Behavior}

Religiosity is "the degree to which a person adheres to his or her religious values, beliefs, and practices, and uses them in daily live" (Worthington et al., 2003, p.85). It has two dimensions: cognitive (intra-personal) and behavioral (inter-personal) (McDaniel \&Burnett, 1990). The cognitive dimension is about people's personal beliefs in religion and the behavior dimension focuses on the degree to which an individual practices the doctrine of his or her religion. Religiosity is important for consumer behavior studies because it is related to consumer behavior variables including lifestyle and retail patronage behavior.It is one of the most important cultural forces that influence behavior, which in turn affects shopping and consumption behavior (Delener, 1990; Hirschman, 1981). For example, Wilkes, Burnett and Howell (1986) found that individuals with a high degree of religiosity are more likely to be opinion leaders and tend to be more satisfied with their lives. They are more traditional in their outlook towards sex and gender roles (Wilkes, et al., 1986). Choi, Kale and Shin (2010) studied the impact of religiosity on consumers' usage of different information sources including significant others, members of the same religious group, media advertisement, impartial sources, and salespeople. The findings suggest that religiosity affects Korean consumers' usage of product information sources. More specifically, religious Korean consumers are more likely to seek information from others in the same religious group, less likely to trust external sources including media, and less likely to use salespeople as an information source 
(Choi et al., 2010). The study (Choi et al., 2010) concluded that the conservative nature of religions may impact highly religious consumers so they become less receptive to external information sources.

\section{Religiosity and Shopping Orientation}

Stone (1954) introduced the concept of shopping orientation which intended to capture consumers' shopping motivation, their desired shopping experiences, and anticipated shopping outcomes. Scholars have defined shopping orientation in a number of ways. Moschis (1992)defined shopping orientation as "mental states that result in various general shopping patterns" (p.394), and Brown, Pope and Voges (2003) defined it as related to general predisposition toward the acts of shopping. Li, Kuo and Russell (1999), on the other hand, conceptualised shopping orientation as a specific portion of lifestyle operationalised by a range of activities, interests and opinion statements that are relevant to the acts of shopping. Therefore, shopping orientation is consumers' general beliefs, feelings, and actions toward shopping. Shopping orientation is a key concept in marketing and patronage behavior research. It is proven to be very useful for understanding and profiling consumers (Moye\&Kincade, 2003). It is also a reliable and important predictor of consumer patronage behavior in the retail environment, both online and offline. For example, it affected consumers' preference for sources of communication (Moschis, 1976), store attributes (Bellenger, Robertson, \&Greenberg, 1977; Shim and Kotsiopulos, 1992), store choices (Darden and Howell, 1987), satisfaction level with information search via multi-channels (Lee and Kim, 2008), and website evaluation criteria (Seock\& Chen-Yu, 2007).

There are many types of shopping orientation. Stone (1954), in his seminar paper on shopping orientation classified consumers as economic shoppers, personalizing shoppers, ethical shoppers, and apathetic shoppers. Darden and Reynold (1971) basically confirmed those four shopper types identified by Stone (1954). Moschis (1976), on the other hand, profiled six different types of shoppers: store loyal, brand loyal, special shopper, psychosocializing, brand name conscious, and problem solving shoppers. Furthermore, Sproles and Kendall (1986) identified eight consumer decision making styles and validated a consumer style inventory (CSI) scale. Those styles include: high-quality consciousness, brand consciousness, novelty-apparel consciousness, recreational shopping consciousness, value for money shopping consciousness, impulsiveness, confusion from over choice, and brand loyal orientation (Sproles\& Kendall, 1986). Based on Sproles and Kendall (1986), each decision making style represented an important mental approach to consumption. However, from the perspective of shopping enjoyment, consumers can be simply classified either as hedonic shoppers or functional shoppers (Bellenger\&Korgaonkar, 1980; Bellenger, Robertson, \& Greenberg, 1977). In conclusion, shopping orientation varies based on consumer characteristics and product category. Visser and Du Preez (2001), for example, proposed nine apparel shopping orientations after intensive review of academic articles on apparel shopping orientation published in the 1980s and 1990s. Those shopping orientations are brand conscious orientation, fashion orientation, finance and credit orientation, opinion leadership orientation, patronage orientation, shopping and time convenience orientation, activates and interests orientation, and confidence versus confusion orientation.

Meanwhile, many factors affect consumers' shopping orientation. Existing studies show income significantly affected the type of store patronized and the choice of payment method (Darden \& Howell, 1987). Other variables such as family life cycle, value, lifestyle, social class, gender, and age were all related to shopping orientation (Howell, 1979; Lumpkin \&Greenberg, 1982). Shim and Kotsiopulos (1992) found that personal characteristics, specifically grooming lifestyle activities, social class and stages of family life cycles were important in predicting apparel shopping orientation. More recently, researchers found that religiosity also significantly affects consumers' shopping orientation (Essoo\&Dibb, 2004; Mokhlis, 2006; Sood\&Nasu, 1995). Using the scenario of purchasing a relatively expensive home radio, Sood and Nasu (1995) explored the effect of religiosity on consumer behavior in Japan and United States. The findings of the study reveal that religiosity significantly affect U.S. Protestants shopping behavior (Sood\&Nasu, 1995). Specifically, more religious Protestants were more economically oriented, that is, they were more likely to purchase products when they are on sale but not when they needed,and preferred stores having lower prices. They also believed there is little relationship between price and 
quality (Sood\&Nasu, 1995). Using the scenario of purchasing a television set, Essoo and Dibb (2004) examined the effect of religion affiliation and religiosity on shopping orientation of Hindus, Muslims and Catholics. The findings reveal that casual religious respondents were more brand conscious, innovative, as well as deals and promotion driven. They also emphasized product and service quality and liked instore credit (Essoo\&Dibb, 2004).

Mokhlis (2006) explored the effect of two dimensions of religiosity, intrapersonal and interpersonal religiosity, on consumer shopping orientation in Kuala Lumpur, Malaysia. The findings suggest that price consciousness, quality consciousness, and impulsive shopping orientation were all significantly related to both intrapersonal religiosity and interpersonal religiosity. The statistical analysis shows that religious consumers, both high on interpersonal and intrapersonal religiosity were quality conscious; that is, religious consumers tended to look for high quality merchandise(Mokhlis, 2006). The mean of price consciousness, however, shows that consumers with high intrapersonal religiosity tended to worry less about price while those with high interpersonal religiosity were more likely to shop for deals.

Overall, findings from existing studies are mixed and inconsistent. While Sood and Nasu (1995) found that devout Protestant Americans were significantly more economically oriented than casual believers, Essoo and Dibb (2004) found that casual religious respondents were more deals and promotional driven, which imply that less religious consumers were more economically oriented. When it comes to brands, Wilkes, et al., (1986) suggested that religious consumers prefer national brands. However, Essoo and Dibb (2004) found that casual religious respondents were more brand-conscious, that is, they value brand name and high-end brands, which suggests that religious consumers were less brand-conscious. Regarding quality, McDaniel and Burnett (1990) found religious consumers were more quality conscious, while Essoo and Dibb (2004) found that casual religious respondents emphasize more on product and service quality which suggests that less religious consumers were more quality conscious.

Inconsistent findings may have several reasons, including special shopping context and product category. Shachar, Erdem, Cutright, and Fitzsimons (2011), for example, conducted a series of studies on the relationship between religiosity and brand reliance which is consumers' choices of name brand merchandise over non-brand or store brand merchandise. Findings of the studies concluded that for socially expressive goods such as apparel, religiosity negatively affected consumers' choice of name brands. That is, when it comes to socially expressive goods, more religious people are less likely to choose branded merchandise (Shachar et al. 2011). But there is not a similar relationship between religiosity and brand reliance when it comes to functional goods such as tools.In conclusion, it is critical to specify product category and target consumer when studying the effect of religiosity on consumer shopping orientation. Therefore, the purpose of this study was to investigate the effect of religiosityon selected consumer apparel shopping orientation: brand consciousness, price consciousness, quality consciousness, fashion consciousness and brand loyalty.

\section{METHODOLOGY}

An online survey was developed to measure consumers' religiosity, apparel shopping orientation, and demographic characteristics including age, gender, annual household income and religious affiliation. For the purpose of this study, the Religious Commitment Inventory, RCI-10(Worthington et al., 2003) was adopted to measure religiosity. This scalewas designed to assess the degree to which a person commits to his or her religious values, beliefs, and practices and uses of them in daily living (Shachar et al., 2011). It has been widely used in the marketing research. It not only was reliable $(\alpha=0.95)$, but also demonstrated strong validity with other religiosity measurements (Worthington et al., 2003). Apparel shopping orientation was measured using scales adopted from consumer style inventory (CSI) developed by Sproles and Kendall (1986). A 5-point Likert-type scale from 1 (strongly disagree) to 5 (strongly agree) was used to measure responses to scale items assessing constructs of interest.

Undergraduate students from two fashion merchandising classes of a major state university in the southwestern United States were instructed to recruit potential participants using social media such as Facebook over a two month period.A total of 668respondents participated in the online survey, resulting 
in 333 usable responses composed of Christian respondents used for this study. Among the respondents, $82.2 \%$ were female. Hispanics and Caucasian whites were two major ethnic groups, accounting for. $37.2 \%$ and $33.8 \%$ respectively. The majority of the respondents, more than $90 \%$, have some college or a college degree. Also, since $46.4 \%$ of respondents were aged from 18-24, the sample characteristics reflected the college student population of the university community in the southwestern United States. More detailed demographic characteristic information is provided in Table 1.

TABLE 1

CHARACTERISTICS OF RESPONDENTS (N=333)

\begin{tabular}{llc}
\hline Characteristics & & Percentage \\
\hline Gender & Male & 17.8 \\
& Female & 82.2 \\
& Missing & .3 \\
\hline Age & $18-24$ & 46.4 \\
& $25-34$ & 25.0 \\
& $35-44$ & 8.1 \\
& $45-54$ & 11.7 \\
& 55 and older & 8.7 \\
\hline Ethnic Group & African American & 7.9 \\
& Asian or Pacific Islander & 13.3 \\
& Caucasian & 33.8 \\
& Hispanic American & 37.2 \\
& Native American & .9 \\
& Others & 6.9 \\
\hline Education & High school graduate & 9.4 \\
& Some College & 39.3 \\
& 2 Year College Degree & 10.3 \\
& 4 Year College Degree & 25.1 \\
& Graduate Degree & 14.5 \\
& Others & 1.5 \\
\hline Household & Less than \$25,000 & 35.6 \\
Income & \$25,000-\$50,000 & 22.2 \\
& \$50,001-\$75,000 & 11.2 \\
& \$75,001-\$100,000 & 14.3 \\
& More than \$100,000 & 16.7 \\
\hline
\end{tabular}

\section{ANALYSIS AND RESULTS}

Structural equation modeling method was used to investigate the effect of religiosity on respondents' shopping orientation. A model was proposed to specify the relationship between religiosity and shopping orientation. SPSS (version 21) was used for data coding, preliminary data analysis, descriptive analysis and factor analysis, and Mplus software (version 6, Muthen\&Muthen, 1998-2010) was used to analyze variance-covariance matrices and test the proposed model. Before the data analysis, allassumptions for multivariate analysis, including multivariate normality and homocedasticity were examined to ensure the data normality. Kline (2005) suggests that there isa problem of multivariate normality when a Kurtosis value is greater than 10. The Kurtosis values of this sample ranged from 1.95 to 2.55 , indicating the data of the study did not have serious problems regarding data normality. The skewness values (using a cut-off range from +1 to -1 ) of the sample also confirmed the normality of the data. Outliers of major variables were excluded for the study analysis (Field, 2005). 
A factor analysis was then conducted using principal axis factoring in order to identify underlying factors of religiosity and respondents' shopping orientations. Following Field's recommendation (2005), factor loadings greater than .50 were considered to be significant with a sample size of 300 . Thus, items with a factor loading of .50 or higher were considered in interpreting the factors. The principle axis factoring analysis with a Promax rotation with Kaiser Normalization revealed only one underlying factor for religiosity. After reviewing all the items, three items with highest factor loadings were selected for structural model analysis (Ullman, 2006).See Table 4 for specific items.

The principle axis factoring analysis with a Promax rotation with Kaiser Normalization revealed five factors with an eigenvalue of one or greater for shopping orientation (see Table 2). The total variance explained by each factor of shopping orientation was also calculated. For instance, the factor 1 has an eigenvalue of 7.08 , which is $32.17 \%$ of the total variance of 5 items (see Table 2). The cumulative percentage of the five factors is $66.64 \%$. A large value of the Kaiser-Mayer-Olkin (K-M-O) measure in this study (0.88) indicates that a factor analysis should yield distinct and reliable factors. The Barlett's test of sphericity is significant (less than .001), suggestingall variables are unrelated and thus the factor analysis is feasible (Hutcheson and Sofroniou 1999).

TABLE 2

TOTAL VARIANCE EXPLAINED

\begin{tabular}{|c|c|c|c|c|c|c|c|}
\hline \multirow[b]{2}{*}{ Component } & \multicolumn{3}{|c|}{ Initial Eigenvalues } & \multicolumn{3}{|c|}{$\begin{array}{c}\text { Extraction Sums of Squared } \\
\text { Loadings }\end{array}$} & \multirow{2}{*}{$\begin{array}{c}\text { Rotation } \\
\text { Sums of } \\
\text { Squared } \\
\text { Loadings } \\
\\
\text { Total } \\
\end{array}$} \\
\hline & Total & $\begin{array}{c}\% \text { of } \\
\text { Variance }\end{array}$ & $\begin{array}{c}\text { Cumulative } \\
\%\end{array}$ & Total & $\begin{array}{c}\% \text { of } \\
\text { Variance }\end{array}$ & $\begin{array}{c}\text { Cumulative } \\
\%\end{array}$ & \\
\hline 1 & 7.08 & 32.17 & 32.17 & 7.08 & 32.17 & 32.17 & 5.64 \\
\hline 2 & 2.51 & 11.39 & 43.56 & 2.51 & 11.39 & 43.56 & 5.46 \\
\hline 3 & 2.05 & 9.34 & 52.90 & 2.05 & 9.34 & 52.90 & 4.15 \\
\hline 4 & 1.64 & 7.45 & 60.35 & 1.64 & 7.45 & 60.35 & 2.19 \\
\hline 5 & 1.38 & 6.28 & 66.64 & 1.38 & 6.28 & 66.64 & 2.34 \\
\hline
\end{tabular}

Extraction Method: Principal Component Analysis.

a. When components are correlated, sums of squared loadings cannot be added to obtain a total variance.

The five factors revealed were labeled: 1) brand consciousness, 2) quality consciousness, 3) fashion consciousness, 4) price consciousness, and 5) brand loyalty. Two items that had no significant loadings on any of the factors above (factor loading less than .50) were eliminated for future statistical analysis because omitting the problematic items (e.g., variable with no significant loadings or with a crossloading) is appropriate if the objective is data reduction (Hair, Black, Babin, \& Anderson, 2010). The finalized five factors were then used in the following structural model analysis to exam the effect of religiosity on the different dimensions of apparel shopping orientation. Please see Table 3 for the summary of items and factor loadings for Promax Rotation of shopping orientations. 
TABLE 3

SUMMARY OF ITEMS AND FACTOR LOADINGS FOR PROMAX ROTATION OF SHOPPING ORIENTATIONS

\begin{tabular}{|c|c|c|c|c|c|c|}
\hline & \multicolumn{5}{|c|}{ Factor Loadings } & \multirow[b]{2}{*}{ Communality } \\
\hline & 1 & 2 & 3 & 4 & 5 & \\
\hline $\begin{array}{l}\text { SO6-The well-known national brands are best } \\
\text { for me. }\end{array}$ & .75 & & & & & .70 \\
\hline $\begin{array}{l}\text { SO7-The more expensive brands are usually } \\
\text { my choice. }\end{array}$ & .75 & & & & & .76 \\
\hline $\begin{array}{l}\text { SO8-The higher the price of a product, the } \\
\text { better its quality. }\end{array}$ & .89 & & & & & .61 \\
\hline $\begin{array}{l}\text { SO9-Nice department and specialty stores } \\
\text { offer me the best products. }\end{array}$ & .78 & & & & & .67 \\
\hline SO10-I prefer buying the best-selling brands. & .87 & & & & & .72 \\
\hline $\begin{array}{l}\text { SO11-I usually have one or more outfits of } \\
\text { the very newest style. }\end{array}$ & & & & & & .66 \\
\hline $\begin{array}{l}\text { SO1-Getting very good quality is very } \\
\text { important to me. }\end{array}$ & & .87 & & & & .75 \\
\hline $\begin{array}{l}\mathrm{SO} 2-\text { When it comes to purchasing apparel, I } \\
\text { try to get the very best or perfect choice. }\end{array}$ & & .78 & & & & .71 \\
\hline $\begin{array}{l}\text { SO3-In general, I usually try to buy the best } \\
\text { overall quality. }\end{array}$ & & .90 & & & & .77 \\
\hline $\begin{array}{l}\text { SO4-I make special effort to choose the best } \\
\text { quality products. }\end{array}$ & & .89 & & & & .79 \\
\hline $\begin{array}{l}\text { SO5-My standards and expectations for } \\
\text { apparel I buy are very high. }\end{array}$ & & .72 & & & & .71 \\
\hline $\begin{array}{l}\text { SO12-I keep my wardrobe up-to-date with } \\
\text { the changing fashions. }\end{array}$ & & & .66 & & & .68 \\
\hline $\begin{array}{l}\text { SO13-Fashionable, attractive styling is very } \\
\text { important to me. }\end{array}$ & & & .83 & & & .70 \\
\hline $\begin{array}{l}\text { SO14-To get variety, I shop different stores } \\
\text { and choose different brands. }\end{array}$ & & & .83 & & & .63 \\
\hline $\begin{array}{l}\text { SO15-It's fun to buy something new and } \\
\text { exciting. }\end{array}$ & & & .77 & & & .56 \\
\hline $\begin{array}{l}\text { SO16-I buys as much as possible at sale } \\
\text { prices. }\end{array}$ & & & & .74 & & .57 \\
\hline $\begin{array}{l}\text { SO17-The lower price products are usually } \\
\text { my choice. }\end{array}$ & & & & .80 & & .64 \\
\hline $\begin{array}{l}\text { SO18-I look carefully to find the best value } \\
\text { for the money. }\end{array}$ & & & & .75 & & .66 \\
\hline $\begin{array}{l}\text { SO19-I have favorite brands I buy over and } \\
\text { over. }\end{array}$ & & & & & .74 & .67 \\
\hline $\begin{array}{l}\text { SO20-Once I find a product or brand I like, I } \\
\text { stick with it. }\end{array}$ & & & & & .79 & .70 \\
\hline $\begin{array}{l}\text { SO21-I go to the same stores each time I } \\
\text { shop. }\end{array}$ & & & & & .65 & .47 \\
\hline SO22-I frequently change brands. & & & & & & .53 \\
\hline
\end{tabular}

Note: The bolded items were selected for the structural equation modeling. 


\section{Structural Equation Modeling}

We used a two-step model-building approach including two conceptually distinct models: a measurement model and a path model (Kline, 2005). Missing data were estimated using Maximum Likelihood estimation, making it possible to use all available information in the dataset. Several model-fit indexes were used to assess confirmatory factor analysis (CFA) and structural equation model fit (SEM). Suggested by Hu \&Bentler (1999), the Comparative Fit Index (CFI) $\geq .95$, Non-Normed Fit Index (NNFI, also known as TLI) $\geq .95$, Root Mean Square Error of Approximation (RMSEA) $\leq .06$, and Standardized Root Mean Square Residual $(\mathrm{SRMR}) \leq 0.08)$ were used to as cut-off lines in this study. Chi-square $(\chi 2)$ difference test was used to compare the model fit among models. The zero-order correlations, means and standard deviations for indicator variables are provided in Table 4.

\section{TABLE 4}

\section{ZERO-ORDER CORRELATIONS, MEANS AND STANDARD DEVIATIONS} FOR INDICATOR VARIABLES

\begin{tabular}{|c|c|c|c|c|c|c|c|c|c|c|c|c|c|c|c|c|c|c|c|c|}
\hline & & 1 & 2 & 3 & 4 & 5 & 6 & 7 & 8 & 9 & 10 & 11 & 12 & 13 & 14 & 15 & 16 & 17 & 18 & 19 \\
\hline 1 & RE3 & 1.00 & & & & & & & & & & & & & & & & & & \\
\hline 2 & RE4 & .81 & 1.00 & & & & & & & & & & & & & & & & & \\
\hline 3 & RE5 & .80 & .84 & 1.00 & & & & & & & & & & & & & & & & \\
\hline 4 & SO1 & .08 & .14 & .13 & 1.00 & & & & & & & & & & & & & & & \\
\hline 5 & $\mathrm{SO} 3$ & .04 & .11 & .09 & .71 & 1.00 & & & & & & & & & & & & & & \\
\hline 6 & $\mathrm{SO} 4$ & .12 & .18 & .12 & .69 & .78 & 1.00 & & & & & & & & & & & & & \\
\hline 7 & SO8 & -.04 & .01 & -.06 & .22 & .21 & .24 & 1.00 & & & & & & & & & & & & \\
\hline 8 & SO9 & .01 & .11 & .05 & .36 & .43 & .44 & .58 & 1.00 & & & & & & & & & & & \\
\hline 9 & SO10 & -.07 & .04 & -.02 & .38 & .36 & .37 & .52 & .66 & 1.00 & & & & & & & & & & \\
\hline 10 & SO13 & .05 & .11 & .05 & .21 & .24 & .25 & .24 & .31 & .26 & 1.00 & & & & & & & & & \\
\hline 11 & SO14 & .03 & .10 & .09 & .21 & .22 & .16 & .14 & .24 & .15 & .52 & 1.00 & & & & & & & & \\
\hline 12 & SO15 & .12 & .17 & .14 & .21 & .17 & .19 & .13 & .19 & .15 & .47 & .48 & 1.00 & & & & & & & \\
\hline 13 & SO16 & .15 & .16 & .16 & .11 & .04 & .06 & .09 & .06 & .01 & .12 & .17 & .18 & 1.00 & & & & & & \\
\hline 14 & SO17 & .01 & .01 & -.01 & -.10 & -.16 & -.14 & -.03 & -.07 & -.13 & -.01 & .01 & .09 & .38 & 1.00 & & & & & \\
\hline 15 & SO18 & .13 & .19 & .21 & .10 & .12 & .09 & -.06 & .02 & -.03 & .11 & .22 & .21 & .49 & .41 & 1.00 & & & & \\
\hline 16 & SO19 & -.01 & .00 & -.02 & .27 & .25 & .23 & .18 & .19 & .19 & .20 & .15 & .18 & .25 & .08 & .24 & 1.00 & & & \\
\hline 17 & $\mathrm{SO} 20$ & .02 & .04 & .04 & .33 & .23 & .21 & .11 & .08 & .07 & .12 & .18 & .18 & .17 & .00 & .17 & .59 & 1.00 & & \\
\hline 18 & age & .22 & .16 & .17 & .00 & .11 & .09 & -.04 & -.05 & -.02 & -.09 & -.10 & -.15 & .08 & -.22 & -.03 & -.06 & -.02 & 1.00 & \\
\hline 19 & income & .15 & .15 & .14 & .03 & .14 & .12 & .01 & .03 & .05 & .04 & .09 & -.02 & -.02 & -.19 & -.01 & .07 & .07 & .49 & 1.00 \\
\hline & Mean & 3.14 & 3.18 & 3.35 & 4.12 & 3.82 & 3.67 & 2.55 & 3.05 & 2.75 & 3.34 & 3.78 & 4.13 & 3.93 & 3.42 & 4.13 & 3.67 & 3.59 & 3.11 & 2.54 \\
\hline & S.D. & 1.36 & 1.37 & 1.34 & .95 & .99 & 1.06 & 1.22 & 1.04 & 1.06 & 1.15 & 1.08 & .97 & 1.08 & 1.13 & .94 & 1.12 & 1.07 & 1.34 & 1.50 \\
\hline
\end{tabular}

\section{Measurement Model}

The measurement model consisted of six latent constructs. A Confirmative Factor Analysis (CFA) was conducted first, and the results revealed that the measurement model fits the data very well: $\chi^{2}(\mathrm{df}=$ $292)=276.33, \mathrm{p}<0.01, \mathrm{CFI}=.98, \mathrm{TLI}=.98, \mathrm{RMSEA}=.044, \mathrm{SRMR}=.033$ with $90 \%$ confidence interval $.023 \sim .043$. All factor loadings in the confirmatory factor analysis for the measurement model were significant (with $\mathrm{t}$ value at $\mathrm{p}<.001$ level), demonstrating convergent validity (Anderson \&Gerbing, 1988). See Table 5 for indicators and their respective loadings. 
TABLE 5

CONFIRMATIVE FACTOR ANALYSIS

Note: $\mathrm{RE}=$ religiosity; $\mathrm{BD}=$ brand conscious; $\mathrm{QL}=$ quality conscious; $\mathrm{FS}=$ fashion conscious; $\mathrm{LY}=$ loyal

\begin{tabular}{|c|c|c|c|c|c|c|c|}
\hline $\begin{array}{l}\text { Latent } \\
\text { Construct }\end{array}$ & Code & Indicators & Beta & B & S.E. & $\begin{array}{c}\mathrm{t}- \\
\text { Value }\end{array}$ & $\begin{array}{l}\text { Cronbach's } \\
\text { Alpha }\end{array}$ \\
\hline \multirow[t]{3}{*}{$\mathrm{RE}$} & RE3 & $\begin{array}{l}\text { It is important to me to spend periods } \\
\text { of time in private religious thought } \\
\text { and reflection. }\end{array}$ & .88 & 1.00 & .00 & - & .93 \\
\hline & RE4 & $\begin{array}{l}\text { Religious beliefs influence all my } \\
\text { dealings in life. }\end{array}$ & .93 & 1.06 & .04 & 24.48 & \\
\hline & RE5 & $\begin{array}{l}\text { Religion is especially important to me } \\
\text { because it answers many questions } \\
\text { about the meaning of life. }\end{array}$ & .91 & 1.02 & .04 & 23.86 & \\
\hline \multirow[t]{3}{*}{$\mathrm{BD}$} & $\mathrm{SO} 8$ & $\begin{array}{l}\text { The higher the price of a product, the } \\
\text { better its quality. }\end{array}$ & .67 & 1.00 & .00 & - & .81 \\
\hline & SO9 & $\begin{array}{l}\text { Nice department and specialty stores } \\
\text { offer me the best products. }\end{array}$ & .86 & 1.09 & .09 & 11.87 & \\
\hline & SO10 & I prefer buying the best-selling brands. & .78 & 1.01 & .09 & 11.66 & \\
\hline \multirow[t]{3}{*}{ QL } & SO1 & $\begin{array}{l}\text { Getting very good quality is very } \\
\text { important to me. }\end{array}$ & .80 & 1.00 & .00 & - & .89 \\
\hline & $\mathrm{SO} 3$ & $\begin{array}{l}\text { In general, I usually try to buy the best } \\
\text { overall quality. }\end{array}$ & .89 & 1.15 & .07 & 17.76 & \\
\hline & $\mathrm{SO} 4$ & $\begin{array}{l}\text { I make special effort to choose the } \\
\text { best quality products. }\end{array}$ & .87 & 1.22 & .07 & 17.47 & \\
\hline \multirow[t]{3}{*}{ FS } & SO13 & $\begin{array}{l}\text { Fashionable, attractive styling is very } \\
\text { important to me. }\end{array}$ & .73 & 1.00 & .00 & - & .74 \\
\hline & SO14 & $\begin{array}{l}\text { To get variety, I shop different stores } \\
\text { and choose different brands. }\end{array}$ & .72 & .92 & .10 & 9.59 & \\
\hline & SO15 & $\begin{array}{l}\text { It's fun to buy something new and } \\
\text { exciting. }\end{array}$ & .66 & .76 & .08 & 9.10 & \\
\hline \multirow[t]{2}{*}{ LY } & SO19 & $\begin{array}{l}\text { I have favorite brands I buy over and } \\
\text { over. }\end{array}$ & .89 & 1.00 & .00 & - & .75 \\
\hline & $\mathrm{SO} 20$ & $\begin{array}{l}\text { Once I find a product or brand I like, I } \\
\text { stick with it. }\end{array}$ & .67 & .72 & .12 & 6.29 & \\
\hline \multirow[t]{3}{*}{ PR } & SO16 & $\begin{array}{l}\text { I buys as much as possible at sale } \\
\text { prices. }\end{array}$ & .66 & 1.00 & .00 & - & .70 \\
\hline & SO17 & $\begin{array}{l}\text { The lower price products are usually } \\
\text { my choice. }\end{array}$ & .52 & .82 & .11 & 7.22 & \\
\hline & SO18 & $\begin{array}{l}\text { I look carefully to find the best value } \\
\text { for the money. }\end{array}$ & .78 & 1.03 & .15 & 7.02 & \\
\hline
\end{tabular}

oriented; $\mathrm{PR}=$ price conscious.

\section{Structural Model}

With an adequate measurement model, the second stage of the structural modeling was performed to estimate the hypothesized path model(Figure 1). Controlling respondents' age and income, the results of the SEM model demonstrated an excellent model fit(Hu \&Bentler, 1999): $\chi^{2}(\mathrm{df}=237)=370.97(\mathrm{p}<.001), \mathrm{CFI}=0.97, \mathrm{TLI}=.96, \mathrm{SRMR}=0.052, \mathrm{RMSEA}=0.042$ with 
$90 \%$ confidence interval .033 .049. Thus, no modification indices were used to re-specify the model. Standardized parameter estimates $(\beta)$ are shown in Figure 1. The results suggest that religiosity has significant direct effects on qualityconsciousness $(\beta=.13, \quad p<.05)$, fashion consciousness $(\beta=.18, p<.01)$, and price consciousness $(\beta=.25, p<.001)$.

\section{FIGURE 1}

\section{THE PATH MODEL RESULTS}

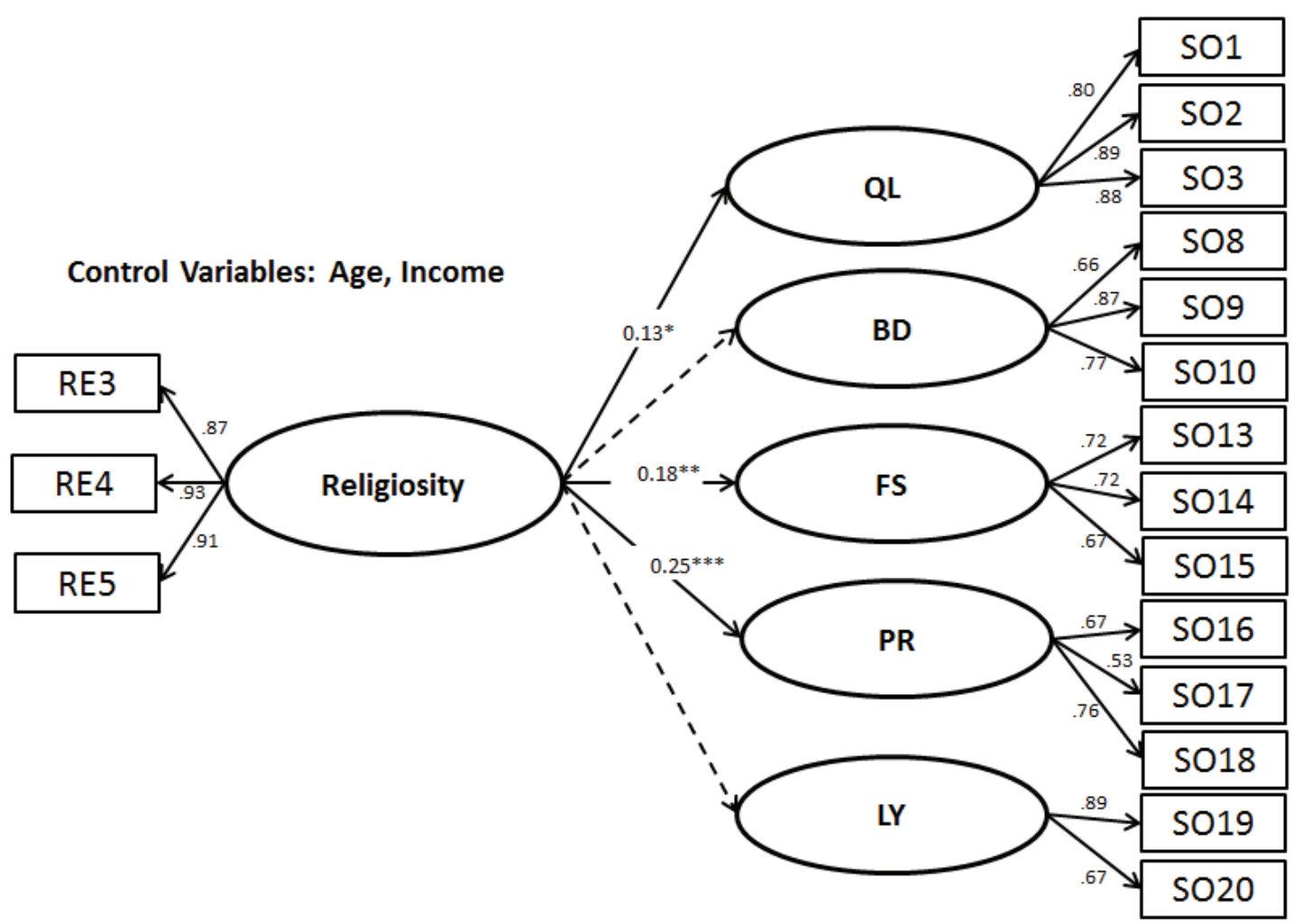

Note: ${ }^{* * *} p<.001 ;{ }^{* *} p<.01 ;{ }^{*} p<.05$; the standardized coefficients are provided along with the significant paths; $\mathrm{QL}=$ quality conscious; $\mathrm{BD}=$ brand conscious; $\mathrm{FS}=$ fashion conscious; $\mathrm{PR}=$ price conscious; $\mathrm{LY}=$ loyal oriented

\section{CONCLUSIONS AND IMPLICATIONS}

Although religion is an important cultural element that affects a society's value system and its people's behavior, limited research has studied effects of religion on consumers' patronage and consumption behavior, especially when it comes to apparel. The purpose of this study, therefore, was to explore the effect of religiosity on Christian consumers' apparel shopping orientation. The findings of this study reveal that religiosity significantly affect Christian's apparel shopping orientation. More specifically, religiosity has a significant positive direct effect on quality consciousness, fashion consciousness, and price consciousness. This finding suggests that the more committed Christians are more quality conscious when it comes to shopping for apparel. They are more likely to seek high quality apparel in the marketplace. However, they are very price-conscious too, that is, they are more likely to shop for sales and lower prices. These findings are consistent with prior studies (McDaniel \& Burnett, 1990; Sood\&Nasu, 1995). Since value is usually defined as a perceived quality relative to the price, the 
findings of the study suggest that more committed Christians are more value orientated. On the other hand, Essoo and Dibb (2004) find that casual religious consumers were more innovative which suggests that they might be more fashion oriented. However, the findings of this study suggest that more committed Christians are more fashion oriented. Finally, the findings of the study reveals that more committed Christians are not brand conscious which supports Essoo andDibb's (2004) finding, and they do not have brand loyalty either.

Overall, the findings of this study picture more committed Christians as more fashion oriented apparel consumers who are more value oriented, meaning focusing on high quality with low prices, but less brand oriented or brand loyal. The conservative value of Christians might have contributed to their value orientation. Value orientation of those consumers might have also led to less brand consciousness and brand loyalty. Less brand consciousness can also be explained by the role of religion in consumers' selfconcept. Shachar et al. (2011) argue that religious consumers are less likely to choose branded merchandise when it comes to socially expressive goods such as apparel because religious consumers are more likely to use their religion rather brand name to express their self-worthiness. Therefore, more religious consumers can be neither less brand conscious nor brand loyal. However, it is interesting to see that more committed Christians are more fashion oriented, which is inconsistent with their conservative image because of their conservative values.

The findings of this study illustrate the importance of understanding the effects of religiosity on consumer patronage behavior in the apparel market. Apparel retailers, especially those that serve markets with high concentration of Christians should try to better understand this subject. Based on the findings of this study, apparel retailers should provide fashion goods with good quality but at reasonable price point. They might also want to explore the specific styles that those consumers prefer, thus to better satisfy their needs and wants. This implies that retailers might also want to focus on developing private brands which focus on value and fashion that can cater to broad Christian consumers.

\section{LIMITATIONS AND FUTURE STUDIES}

There are several limitations of this study. The first limitation is the measurement issue. Religiosity may not be the most effective and efficient measure for studies on religion and consumer behavior (Muhamad\&Mizerski, 2010). Other measurements such as religious motivation whichis the most established construct measuring religion and human behavior (Donahue, 1985) should be explored in the future. The second limitation is the lack of consideration of other variable such as religious values themselves. Swinberghe, Flurry, and Parker (2011) found that Christian conservative values significantly affect consumers' forming ethical judgment on retailers and subsequent marketplace behaviors, and argued that conservatism might be a necessary variable when evaluating the effectiveness of religion in the marketplace. Therefore, future studies might want to add religious values as important variables. The last limitation is the sampling method. A convenient sample with large percentage of young (18-24) consumer was used in this study. A future study with a random sample is also recommended.

\section{REFERENCES}

Anderson, J. C., \&Gerbing, D. W. (1988). Structural equation modeling in practice: A review and recommended two-step approach. Psychological Bulletin, 103(3), 411.

Bailey, J. M., \&Sood, J. (1993). The effects of religious affiliation on consumer behavior: A preliminary investigation. Journal of Managerial Issues, 3(5), 325-382.

Bellenger, D. N., \&Korgaonkar, P. K. (1980). Profiling the recreational shopper.Journal of Retailing, 56(3), 77-92.

Bellenger, D. N., Robertson, D. H., \& Greenberg, B. A. (1977). Shopping center patronage motives.Journal of Retailing, 53(2), 29-38. 
Brown, M., Pope, N., \&Voges, K. (2003). Buying or browsing?: An exploration of shopping orientations and online purchase intention. European Journal of Marketing, 37(11/12), 1666-1684.

Christian consumer segment ready to switch to compatible brands (2012). Retrieved July 26, 2013, from http://www.thestoneagency.com.

Choi, Y., Kale, R., \& Shin, J. (2010). Religiosity and consumers' use of product information source among Korean consumers: An exploratory research. International journal of consumer studies, 34(1), 61-68.

Cleveland, M., \& Chang, W. (2009). Migration and materialism: The roles of ethnic identity, religiosity, and generation. Journal of Business Research, 62(10), 963-971.

Darden, W. R., \& Howell, R. D. (1987). Socialization effects of retail work experience on shopping orientations. Journal of the Academy of Marketing Science, 15(3), 52-63.

Darden, W. R., \& Reynolds, F. D. (1971). Shopping orientations and product usage rates. Journal of Marketing Research, 505-508.

Delener, N. (1990). The effects of religious factors on perceived risk in durable goods purchase decisions. Journal of Consumer Marketing, 7(3), 27-38.

Delener, N. (1994). Religious contrasts in consumer decision behaviour patterns: Their dimensions and marketing implications. European Journal of Marketing, 28(5), 36-53.

Donahue, M. J. (1985). Intrinsic and extrinsic religiousness: The empirical research. Journal for the Scientific Study of Religion, 418-423.

Durkheim, E. (1912). The Elementary Forms of Religious Life: Oxford University Press.

Essoo, N., \&Dibb, S. (2004). Religious influences on shoppingbehaviour: An exploratory study. Journal of Marketing Management, 20(7-8), 683-712.

Field, A. (2005). Discovering Statistics with SPSS (Vol. 27). London, U.K.: Sage.

Hair, J. F., Black, W. C., Babin, B. J., \& Anderson, R. E. (2010). Multivariate Data Analysis. Upper Saddle River, NJ: Prentice Hall.

Howell, R. D. (1979). Multivariate examination of a patronage model: The impact of values and life style on shopping orientations. University of Arkansas.

Hu, L. T., \&Bentler, P. M. (1999). Cutoff criteria for fit indexes in covariance structure analysis: Conventional criteria versus new alternatives. Structural Equation Modeling: A Multidisciplinary Journal, 6(1), 1-55.

Hutcheson, G. D., \&Sofroniou, N. (1999). The multivariate social scientist: Introductory statistics using generalized linear models: Sage Publications Limited.

Hirschman, E. C. (1981). American Jewish ethnicity: Its relationship to some selected aspects of consumer behavior. Journal of Marketing, 45(3).

Hirschman, E. C. (1982). Religious differences in cognitions regarding novelty seeking and information transfer. Advances in Consumer Research, 10, 228-233.

Kline, R. B. (2005). Principles and practice of structural equation modeling Guilford.New York, 366.

Lee, H.-H., \& Kim, J. (2008). The effects of shopping orientations on consumers' satisfaction with product search and purchases in a multi-channel environment.Journal of Fashion Marketing and Management, 12(2), 193-216.

Li, H., Kuo, C., \&Rusell, M. G. (1999). The impact of perceived channel utilities, shopping orientations, and demographics on the consumer's online buying behavior.Journal of Computer-Mediated Communication, 5(2), 0-0.

Lumpkin, J. R., \& Greenberg, B. A. (1982). Apparel-shopping patterns of the elderly consumer.Journal of Retailing, 58(4), 68-89.

McDaniel, S. W., \& Burnett, J. J. (1990). Consumer religiosity and retail store evaluative criteria. Journal of the Academy of Marketing Science, 18(2), 101-112.

Mokhlis, S. (2006). The effect of religiosity on shopping orientation: an exploratory study in Malaysia. Journal of American Academy of Business, 9(1), 64-74.

Mokhlis, S. (2009). Relevancy and measurement of religiosity in consumer behavior research.International Business Research, 2(3), P75. 
Moschis, G. P. (1976). Shopping orientations and consumer uses of information. Journal of Retailing, $52(2), 61$.

Moschis, G. P. (1992). Marketing to Older Consumers. Westport. Conn.

Moschis, G. P., \& Ong, F. S. (2011). Religiosity and consumer behavior of older adults: A study of subcultural influences in Malaysia. Journal of Consumer Behaviour, 10(1), 8-17.

Moye, L. N., \&Kincade, D. H. (2003). Shopping orientation segments: Exploring differences in store patronage and attitudes toward retail store environments among female apparel consumers. International Journal of Consumer Studies, 27(1), 58-71.

Muhamad, N., \&Mizerski, D. (2010). The constructs mediating religions' influence on buyers and consumers.Journal of Islamic Marketing, 1(2), 124-135.

PewForumonReligionandPublicLife. (2008). U.S. religious landscape survey. Retrieved January 27, 2014, from http://www.pewforum.org/files/2013/05/report-religious-landscape-study-full.pdf.

Seock, Y. K., \& Chen-Yu, J. H. (2007). Website evaluation criteria among US college student consumers with different shopping orientations and Internet channel usage. International Journal of Consumer Studies, 31(3), 204-212.

Shachar, R., Erdem, T., Cutright, K. M., \& Fitzsimons, G. J. (2011). Brands: The opiate of the nonreligious masses? Marketing Science, 30(1), 92-110.

Sheth, J. N. (1983). An integrative theory of patronage preference and behavior. In W. R. Darden, \&R. F. Lusch, (Eds.),Patronage behavior and retail management. New York, NY: North-Holland.

Shim, S., \&Kotsiopulos, A. (1992). Patronage behavior of apparel shopping: Part I. Shopping orientations, store attributes, information sources, and personal characteristics. Clothing and Textiles Research Journal, 10(2), 48-57.

Sood, J., \&Nasu, Y. (1995). Religiosity and nationality: An exploratory study of their effect on consumer behavior in Japan and the United States.Journal of Business Research,34(1), 1-9.

Sprotles, G. B., \& Kendall, E. L. (1986). A methodology for profiling consumers' decision-making styles.Journal of Consumer Affairs,20(2), 267-279.

Stone, G. P. (1954). City shoppers and urban identification: observations on the social psychology of city life. American Journal of Sociology, 36-45.

Swimberghe, K., Flurry, L. A., \& Parker, J. M. (2011). Consumer religiosity: Consequences for consumer activism in the United States. Journal of Business Ethics, 103(3), 453-467.

Swimberghe, K., Sharma, D., \& Flurry, L. (2009). An exploratory investigation of the consumer religious commitment and its influence on store loyalty and consumer complaint intentions.Journal of Consumer Marketing, 26(5), 340-347.

Targeting the $\$ 1.75$ trillion faith driven consumer market (2012). Retrieved July 26, 2013 from http://www.faithnomics.com/2012/04/26/targeting-the-1-75-trillion-faith-driven-consumermarket/.

Ullman, J. B. (2006). Structural equation modeling: Reviewing the basics and moving forward. Journal of Personality Assessment, 87(1), 35-50.

Visser, E. M., \& Du Preez, R. (2001). Apparel shopping orientation: Two decades of research. Journal of Family Ecology and Consumer Sciences, 29(1).

Wilkes, R. E., Burnett, J. J., \& Howell, R. D. (1986). On the meaning and measurement of religiosity in consumer research. Journal of the Academy of Marketing Science, 14(1), 47-56.

Worthington Jr, E. L., Wade, N. G., Hight, T. L., Ripley, J. S., McCullough, M. E., Berry, J. W., ... \& O'Connor, L. (2003). The Religious Commitment Inventory--10: Development, refinement, and validation of a brief scale for research and counseling.Journal of Counseling Psychology,50(1), 84. 